Article

\title{
The Importance Given to Food Naturalness Attributes by Millennial University Students
}

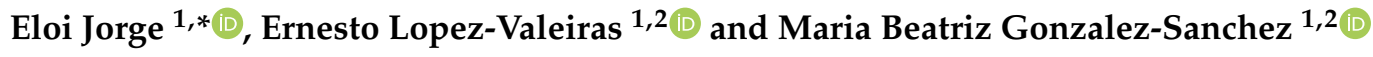 \\ 1 Research Group in Economic Analysis, Accounting and Finance (RGEAF), University of Vigo, \\ 36310 Vigo (Pontevedra), Spain; elvaleiras@uvigo.es (E.L.-V.); bgonzale@uvigo.es (M.B.G.-S.) \\ 2 Accounting and Finance Department, Faculty of Business Administration and Tourism, University of Vigo, \\ 32004 Ourense, Spain \\ * Correspondence: edias@uvigo.es
}

Received: 28 November 2019; Accepted: 17 January 2020; Published: 19 January 2020

\begin{abstract}
So-called natural food is one of the most significant current trends in the food business. Despite this trend, previous research on the measurement of naturalness has made no distinction between different groups of consumers. Therefore, the objective of this study is to explore the attributes important to millennial university students when evaluating food naturalness. The study is based on a questionnaire administered to a sample of 372 respondents. Using a partial least square (PLS) methodology, it performs a standard confirmatory factor analysis for measurement and validations. As a result, it identifies one attribute linked to how the food is grown and eight attributes associated to how it is produced and processed. These findings have several implications. Apart from testing previous scales in a millennial context, they confirm that market strategies must take different understandings of naturalness into account contingent upon the consumer group.
\end{abstract}

Keywords: food naturalness; millennials; trust; importance

\section{Introduction}

The purpose of this paper is to explore attributes important to millennial university students when evaluating food naturalness. It cannot be disregarded that present and future tendencies of food consumption are specified by what millennials value the most [1-5]. The importance of food naturalness for consumers and its impact on their behavior has been widely studied in the literature (e.g., [6-9]). Among others, previous studies have suggested attributes such as the absence of additives and the presence of natural ingredients [10,11], being unprocessed [12], or containing organically grown products [13]. However, the attributes considered important when evaluating food naturalness may vary across consumers and different stakeholder groups [9]. In particular, the millennial generation shows peculiarities in attitudes, behavior, and lifestyle that may set millennials far from other generations and could, therefore, compromise the applicability of previous findings. To the best of our knowledge, no study to date has analyzed attributes important to this subset of consumers when evaluating food naturalness. This paper aims to shed more light on this issue.

Millennials (also called Generation Y) are people born between 1982 and 2000 [5]. It should be noted, however, that an accurate definition of the millennial generation varies from one source to another (e.g., [14-19]). They are characterized for adding more value to authenticity [2], having more concern about what they eat [7], having an elevated preference for local food [20], and exhibiting knowledge about the value and quality of products [19]. The millennial generation is of current interest to researchers and represents an attractive segment for food businesses across the globe [1,21].

In this study, we draw on the framework of Román et al. [9] to identify how relevant food naturalness attributes are to millennial university students. Noticing a lack of consensus about the 
measurement of food naturalness, Román et al. [9] conducted an integration study of the existing empirical evidence on this topic. As a result, they provided a guiding framework with three separate yet related categories describing: (1) How the food is grown (relating to its origin), which includes two attributes; (2) the way the food is produced and processed, with nine attributes; and (3) the properties of the final product (representing the result or outcome), which comprises four attributes. Following the reasoning of Michel and Siegrist [22], our scale excludes attributes that could be used as dependent variables in research models attempting to predict purchasing behavior. This means it takes no account of the attribute related to organic farming (included in Category 1) and the four attributes related to the perceived properties of the final product (Category 3 ).

The study consisted of a sample of 372 Spanish university students. A standard confirmatory factor analysis, using partial least squares (PLS), was conducted for measurement validation. The findings show that this consumer group not only highly regards the attributes related to "how the food in produced and processed", but also gives importance to the ones related to "how the food is grown". Unlike previous research (e.g., [22]), the results of our study present evidence indicating that millennials do not consider "traditional" production methods as a relevant naturalness attribute to be included in the "way the food is produced and processed" category. Thus, the results are useful because they provide new insights into native scales.

The remainder of this paper is structured as follows. Section 2 introduces the theoretical framework. Section 3 describes the research methodology. The fourth section analyzes the data and presents the results. The fifth section discusses and interprets the empirical findings, and in Section 6, the main conclusions, limitations, and lines of future research are presented.

\section{Food Naturalness and Millennials' Behavior}

Millennials constitute a prime group of consumers, and will do so even more over the next few decades $[1,7,21]$. They represent the largest generational cohort $[2,23]$, so their purchasing power makes them an appealing target group for many consumer industries and attracts many companies towards understanding the needs and behavior of this customer base. Consequently, millennials have become a remarkable group for study given their distinctive behavior as compared to other generations [7], their sharing of common values [24,25], enjoyment of life experiences [26], pursuance of specific motivations [3,5,14,27], and purchasing behavior [24,28]. Millennials are characterized as having a higher education level than other generations [1,29] or by the intensive use and adaptation of technology in their daily lives [17,28,30,31]. This consumer group exhibits different food purchasing behavior from other groups, are highly aware of their eating habits [7,31], and are more likely to come across an innovative food product on the market in a near future [24]. Furthermore, it is believed that millennials are perceived to be "more natural than any other generational group" [7].

The multidimensionality of the importance of naturalness for consumers has been discussed by a number of scholars, who have identified a wide range of attributes used for measuring this concept [6,8,13,32-37], leading to a lack of consensus about its definition [6]. According to Chambers et al. [34], the lack of consensus is owed to the fact that the importance given to natural food by consumers requires a broader definition and therefore a wider range of attributes; it cannot be contemplated in a single attribute.

Researchers have had a difficult time accurately gauging consumers' perceived importance of food naturalness, perhaps because food naturalness differs depending on the circumstances in which food naturalness is discussed [9]. Michel and Siegrist [22] suggest that previous studies debating this concept may have some problematic issues in its predictive power, which has led to an unexplained divergence in its measures. This paper considers ten attributes from Román et al. [9], to attempt to first define food naturalness in order to help clarify these difficulties within a specific consumer-interest set; millennials.

Local food production is an attribute belonging to Roman's category of "how the food is grown". Local production is often linked to the sustainability of rural development [38-40]. According to 
Feldmann and Hamm [41], consumers' definition of local food depends on their perceptions. This concept ranges "from distances (i.e., miles or kilometers), political boundaries, and specialty criteria, to more holistic approaches that also include emotional and/or ethical dimensions such as personal relations with or within the region" (p. 156). In contrast to other concepts related to the origin of food, namely organic farming [42], local production does not have adequate regulation and a certified labeling system [41].

Regarding the category of "how the food is produced", Román et al. [9] aggregated the different attributes as follows: The absence of harmful components, the presence of certain positive elements, and the production process. Specifically, the absence of certain ingredients encompasses six-attribute measures. "Artificial ingredients" (1) are used to change food appearance properties [43]. "Preservatives" (2) are used to extend the shelf-life of processed foods by maintaining the food's quality with the inhibition of microbiological changes that occur in the product's lifetime [44]. In turn, "additives" (3), natural or synthetic, are used not only to give food a better taste but also to improve the color and shape of the food [44]. Preservatives and additives, which are frequently correlated [44-46], contribute to reducing the perceived naturalness of food products [47]. "Artificial colors and flavors" (4), in a similar way to artificial ingredients, are used to change the natural appearance and taste of food products $[43,46]$, with the former helping these products to maintain their visual appearance during their shelf-life [43,46] and the latter enhancing or modifying its flavors [48]. Although not an ingredient, residues from "chemicals," "hormones", and "pesticides" (5) are identified by [8] as harmful elements that interfere with food naturalness. This category also includes consumers' rejection of genetically modified organisms (GMO) (6), meaning that food does not preserve its natural properties [13,48,49] and contains traces of transferred genetic material in its DNA as a consequence of its preparation process [40,48].

In contrast to the absence of certain ingredients, such as those previously described that can be correctly identified as "free from," the next attribute, the "presence of" natural ingredients (7), is much more ambiguous and difficult to define from a consumer perspective [34]. "Natural" cannot be considered an ingredient itself, but "natural ingredients" are those without synthetic additives [32] or those that are not genetically modified $[13,48,49]$. In addition to the absence or presence of certain ingredients, Román et al. [9] also considered the production process in the "how the food in produced" category, which includes the degree of "processing" (8) and the use of "traditional" methods (9) in its preparation. A high degree of food processing is commonly associated with foods being more "unnatural and full of chemicals" ([50], p. 683) and with consumers becoming suspicious about the final product because they do not know the ingredients used in the preparation of the food [33]. Furthermore, the use of "traditional" production methods is viewed as an "old-style" home-made family-farm food production that respects and accepts local customs [51-53].

\section{Materials and Methods}

\subsection{Procedure and Sample}

This study is part of a larger research project. A quantitative research survey was distributed among millennial students from a public university in Spain. We followed similar studies (e.g., [21]) and collected these data via a paper-based survey using a convenience sample of potential respondents. The data collection period was between November 2017 and March 2018. The survey instrument was presented to participants and included demographic details and statements related to the perceived importance of food naturalness based on the theoretical framework of Román et al. [9]. The sample consisted of 372 respondents, representing the target population for this paper. Our respondents were aged between 18 and 25 at the time of the survey. According to Hinkin [54], our sample represents a satisfactory sample size for confirmatory factor analysis. Table 1 presents the frequencies by gender, age, and income. 
Table 1. Demographic characteristics of the participants $(N=372)$.

\begin{tabular}{llcc}
\hline Demographic and Personal Characteristics & Category & Frequency & $\%$ \\
\hline \multirow{2}{*}{ Gender } & Male & 162 & 43.5 \\
& Female & 210 & 56.5 \\
\hline \multirow{2}{*}{ Age } & $18-21$ & 248 & 66.7 \\
& $22-25$ & 124 & 33.3 \\
\hline \multirow{3}{*}{ Monthly disposable income } & $\leq 1000$ & 45 & 12.1 \\
& $1001-2000$ & 132 & 35.5 \\
& $2001-3000$ & 104 & 28.0 \\
& $3001-4000$ & 40 & 10.8 \\
& $>4000$ & 29 & 7.8 \\
& No answer & 22 & 5.9 \\
\hline
\end{tabular}

\subsection{Measures}

The final version of the questionnaire was structured, retaining all the demographic data and with the eleven items describing food naturalness, with "how the food is produced" (9) and "how the food is grown" (2) grouped into two separate categories. Table 2 lists these items and briefly describes each item. These items were measured by having participants indicate their level of agreement with the statements proposed [42], using a 5-point Likert scale ranging from 1 "strongly disagree" to 5 "strongly agree."

Consonant with that suggested in the literature (e.g., [54]), exploratory factor analysis was conducted in order to reduce the number of items. R 3.6.1 GUI 1.70 software, Rcmdr Version 2.6-0, and the FactoMineR package were used for this analysis. Following Hinkin's suggestion [54], the principle axis method and varimax rotation factor analysis were used. The resultant factor matrix has shown that most items had high loadings on only one factor, the adequacy of each item was considered for a factor loading if it was greater than 0.4 , and cross-loading less than $0.35[54,55]$ items that did not load well on their intended factor or loaded strongly on multiple factors were removed. Table 3 illustrates the results of this exploratory analysis. It must be noted, however, that this analysis was performed considering the theorized "how the food is produced" and the "how the food is grown" attributes of Román et al. [9]. Besides exploratory factor analysis, and following Hinkin's recommendations [54], item reduction was considered along inter-item correlation. Nevertheless, in respect of this criterion, no items correlated less than the cut-off value of 0.40 , so no items were removed from this analysis. 
Table 2. Compilation of food naturalness importance attributes and measurement items.

\begin{tabular}{|c|c|c|c|}
\hline \multirow{2}{*}{ Categories } & \multirow{2}{*}{ Attributes } & \multirow{2}{*}{ Item } & Measurement Item \\
\hline & & & Indicate the Degree of Agreement with Each of the Following Statements ... \\
\hline \multirow{9}{*}{ How the food is produced } & Artificial ingredients & HP1 & "... it is important to me to avoid all types of artificial ingredients if possible." \\
\hline & Preservatives & HP2 & $\begin{array}{l}\text { "... it is important to me that the food I eat on a typical day is free of chemical } \\
\text { preservatives." }\end{array}$ \\
\hline & Additives & HP3 & "... it is important to me that the food I eat on a typical day contains no additives." \\
\hline & Artificial colors and flavors & HP4 & $\begin{array}{l}\text { "... it is important to me that food does not contain artificial colors and flavor } \\
\text { enhancers." }\end{array}$ \\
\hline & Chemicals, hormones, and pesticides & HP5 & "... it is important to me that food does not contain residues from chemicals." \\
\hline & GMOs & HP6 & $\begin{array}{l}\text { "... it is important to me that the food I eat does not contain genetically modified } \\
\text { organisms (GMOs)." }\end{array}$ \\
\hline & Natural ingredients & HP7 & $\begin{array}{l}\text { "... it is important to me that the food I eat on a typical day contains natural } \\
\text { ingredients." }\end{array}$ \\
\hline & Minimally processed & HP8 & "... it is important to me that the food I eat is minimally processed." \\
\hline & Traditional production methods & HP9 & "... it is important to me to eat traditional/"artisanal" style foods." \\
\hline \multirow{2}{*}{ How the food is grown } & \multirow{2}{*}{ Local } & HG1 & "... it is important to me that the food I eat it is grown in my region." \\
\hline & & HG2 & "... it is important to buy traditional products from my region." \\
\hline \multirow{2}{*}{ Trust } & & $\mathrm{T} 1$ & "I trust natural food." \\
\hline & & $\mathrm{T} 2$ & "I trust that natural food is better than conventional food." \\
\hline
\end{tabular}


Table 3. Exploratory factor analysis.

\begin{tabular}{ccc}
\hline Item & Factor $\mathbf{1}$ & Factor $\mathbf{2}$ \\
\hline HP1 & $\mathbf{0 . 7 6 7}$ & - \\
HP2 & $\mathbf{0 . 8 5 8}$ & 0.103 \\
HP3 & $\mathbf{0 . 8 6 7}$ & 0.143 \\
HP4 & $\mathbf{0 . 6 6 2}$ & 0.132 \\
HP5 & $\mathbf{0 . 4 5 6}$ & 0.120 \\
HP6 & $\mathbf{0 . 5 3 4}$ & 0.209 \\
HP7 & $\mathbf{0 . 5 2 4}$ & - \\
HP8 & $\mathbf{0 . 6 2 0}$ & 0.117 \\
HP9 & $\mathbf{0 . 2 3 7}$ & 0.237 \\
HG1 & 0.170 & $\mathbf{0 . 7 1 9}$ \\
HG2 & 0.106 & $\mathbf{0 . 9 8 0}$ \\
\hline
\end{tabular}

The highest loadings are marked in bold. HP = How the food is produced; HG = How the food is grown.

The results obtained from the exploratory factor analysis revealed a single item (HP9) that loaded below the threshold value (0.237), which was considered for removal. After removing this item and reanalyzing the data, the items were clearly assigned to two factors as follows: "how the food is produced" (Factor 1) and "how the food is grown" (Factor 2).

In addition to the "how the food is produced" and "how the food is grown" items shown in Table 2, a two-item measure of "trust", derived from Román et al. [9], was also included to further assess the effects of the "how the food is produced" and "how the food is grown" constructs on a relevant criterion variable. According to Vega-Zamora et al. [56], the choice of one product over another depends on the consumers' perceived benefits. Accordingly, the preference for natural food does not always translate into purchasing these foods [8] because it depends on other factors, such as the willingness to pay premium prices $[6,8,57-59]$, the product label information $[15,59,60]$, and the variety and availability of natural food for purchasing [57]. However, there is a consensus among the literature that "trust" could be a predictor of consumer intentionality and behavior $[8,56,61,62]$. However, "trust" is not easy to define because it varies depending on the context, interest surrounding it, and disciplines $[56,62,63]$. The present research follows the functional "trust" definition of Vega-Zamora et al. [56], which is related to attributes important to the consumer and this dimension of "trust" is defined as "the belief or conviction that a product effectively fulfils a function, has a certain attribute or helps to solve a problem, within the determining characteristics in the choice process" (pp. 512-513).

\section{Results}

A standard confirmatory factor analysis using partial least squares-structural equation modeling (PLS-SEM) was conducted for measurement and validation of the research model. We used the latest version of the PLS-SEM (v.3.2.8) to analyze the data. The bootstrapping option was employed with 5000 subsamples to test the significance of the path coefficients [64].

To assess the reliability and convergent validity of the reflective constructs, this study carried out a confirmatory factor analysis following Hair et al.'s recommendations [64] by using the following measures: Composite reliability (CR) and Cronbach's alpha (CA) were used to assess the construct reliability, and the outer loadings of the indicators and the average variance extracted (AVE) were used to assess the convergent validity, as shown in Table 4. It also presents the mean and standard deviation for the remaining items. To examine the discriminant validity of the reflective model, in particular, the heterotrait-monotrait (HTMT) ratio and the Fornell-Larcker criterion were used [64-66] (Table 4). As shown in Table 3, the three constructs, "how the food is produced," "how the food is grown," and "trust," had composite reliability scores between 0.88 and 0.93 , suppressing the cut-off value of 0.70 [67]. Therefore, the construct reliability for the internal structural fit of all the latent variables is good. The lowest value found for Cronbach's alpha was 0.74 , which also exceeds the recommended threshold of 0.70 for all the constructs [68]. All item loadings are larger than the standardized value of 0.70 [66] or are very close to this value in all correlations. A measurement and validation of the research model was also computed before proceeding to item reduction as a robustness check, to determine which 
items best represent each category. All item loadings were over 0.70 or were very close to this value in all the correlations; the weakest value was 0.56 for "traditional". Even though weaker values could be set to retain, it made no contribution to content validity in this study [64], so it was set for removal. For the AVE, the scales are all above the cut-off values of 0.50 for AVE [67], which reveals that the constructs have higher reliability [68]. The results confirm that the measurement model is considered satisfactory with adequate support for reliability and convergent validity [67].

Table 4. Measurement model results (descriptive statistics, factor loadings, item reliability, and convergent validity).

\begin{tabular}{|c|c|c|c|c|c|c|c|}
\hline Construct & Item & Mean & Standard Deviation & Factor Loading & CR & AVE & CA \\
\hline \multirow{5}{*}{$\begin{array}{l}\text { How the food is } \\
\text { produced }\end{array}$} & HP2 & 3.245 & 1.160 & 0.837 & \multirow{5}{*}{0.928} & \multirow{5}{*}{0.620} & \multirow{5}{*}{0.912} \\
\hline & $\mathrm{HP} 4$ & 2.968 & 1.119 & 0.709 & & & \\
\hline & HP5 & 3.808 & 1.114 & 0.653 & & & \\
\hline & HP6 & 3.148 & 1.046 & 0.764 & & & \\
\hline & HP8 & 3.689 & 1.015 & 0.853 & & & \\
\hline \multirow{2}{*}{ How the food is grown } & HG1 & 3.736 & 1.057 & 0.943 & \multirow[t]{2}{*}{0.936} & \multirow[t]{2}{*}{0.880} & \multirow[t]{2}{*}{0.864} \\
\hline & HG2 & 3.621 & 1.087 & 0.933 & & & \\
\hline \multirow{2}{*}{ Trust } & $\mathrm{T} 1$ & 4.085 & 0.858 & 0.894 & \multirow[t]{2}{*}{0.886} & \multirow[t]{2}{*}{0.796} & \multirow[t]{2}{*}{0.744} \\
\hline & $\mathrm{T} 2$ & 4.146 & 0.887 & 0.891 & & & \\
\hline
\end{tabular}

In terms of discriminant validity, the highest HTMT value in the whole model is 0.50 (Table 5), which means, according to Henseler et al. [65], that the more conservative HTMT ratio should be used $(<0.85)$. This criterion was also fulfilled in this study. Additionally, the Fornell-Larcker criterion was used as a second approach for validating the discriminant validity. The square root of the AVE of each construct is higher than any correlation between them, which is a condition to provide evidence for the constructs' discriminant validity [64]. This condition was also fulfilled.

Table 5. Discriminant validity assessment.

\begin{tabular}{lccc}
\hline & How the Food is Produced & How the Food is Grown & Trust \\
\hline How the food is produced & $\mathbf{0 . 7 8 7}$ & 0.398 & 0.501 \\
How the food is grown & 0.361 & $\mathbf{0 . 9 3 8}$ & 0.346 \\
Trust & 0.430 & 0.278 & $\mathbf{0 . 8 9 2}$ \\
\hline
\end{tabular}

Values on the diagonal are the square roots of the AVE. Values below the diagonal are the correlations between the factors. Values above the diagonal are the heterotrait-monotrait (HTMT) ratios.

To assess the performance of "how the food is produced" and "local production" in a greater nomological network, we included the measure of "trust" in a predictive structural equation model. Table 6 shows the estimations of the standardized regression coefficients of the constructs (standard deviation) and their corresponding t-statistics. The estimated values confirm the statistical significance of the coefficients related to each of the proposed relationships. The results presented in Table 6 corroborate the appropriateness of the indicators selected. The obtained values also confirm the positive relation, statistically very significant, at $p<0.001$, between "how the food is produced" and "trust", and at $p<0.01$, between local production and "trust". In the case of evaluating the structural model, the estimated values of the $\mathrm{R}^{2}$ statistic were 0.20 . According to Akter et al. [69], these values range in the medium-effect interval. Therefore, the acceptability criterion proposed by Hair et al. [64] for disciplines such as consumer behavior has been accomplished. For this evaluation, a blindfolding procedure was also applied to assess the predictive relevance of the theoretical model $\left(\mathrm{Q}^{2}\right)$ [70], particularly for this proposed cross-validated redundancy [71]. The redundancy index measures the quality of the structural model for each endogenous construct [72] and can provide an overall validation of the model. 
A $\mathrm{Q}^{2}$ greater than 0 , such as that obtained in the present research, implies that the model has predictive relevance [73]. The indices for redundancy and explained variability $\left(R^{2}\right)$ are given in Table 6.

Table 6. Direct effects between latent variables and structural model evaluations.

\begin{tabular}{lcccccc}
\hline & Standard Deviation & Original Sample & T Statistics & $\mathbf{R}^{2}$ & Redundancy $\left(\mathbf{Q}^{2}\right)$ & $p$-Value \\
\hline $\begin{array}{l}\text { How the food is } \\
\text { produced } \rightarrow \text { Trust }\end{array}$ & 0.047 & 0.380 & 8.020 & & & $<0.001$ \\
$\begin{array}{l}\text { How the food is grown } \\
\rightarrow \text { Trust }\end{array}$ & 0.054 & 0.141 & 2.593 & 0.202 & 0.151 & $<0.01$ \\
\hline
\end{tabular}

As shown (Table 6), the relationships in the proposed model were verified, revealing the relevance of the two categories: (1) "how the food is produced" and (2) "how the food is grown" in its relationship with consumers' "trust" in food naturalness. These results extend and complement those presented by Román et al. [9] and Michel and Siegrist [22].

\section{Discussion}

The purpose of this study is to explore the attributes of food naturalness important to millennial university students. This analysis was built upon the framework of Román et al. [9]. To the best of the authors' knowledge, the present research constitutes the first attempt to investigate the importance of different food naturalness attributes from two separate but connected categories-"how the food is grown" and "how food is produced"- that especially take into account their effect as predictors of consumer intentionality.

The structure of the naturalness scale was examined using exploratory factor analysis. All the items of the proposed scale were statistically significant and corresponded to two different categories, with the exception of the "traditional" production methods attribute that does not seem to relate to "how the food is produced" for millennial university consumers. This is why it was considered for removal. The non-inclusion of this attribute in a naturalness scale extends previous studies (e.g., [22]) and highlights a specificity of millennials as compared to non-specific groups of consumers. Some factors may explain the lack of importance of "traditional" food for millennials. On the one hand, previous literature on consumer behavior finds that demographic characteristics, namely age, have an impact on the acceptance of "traditional" food; an "old-style" food typically consumed by middle-aged consumers [74]. On the other hand, unlike other stakeholder groups, millennials tend to be earlier adopters of new food products [23]. They show more interest in an innovative combination of ingredients to create a greater diversity of flavors, shapes and/or textures, usually set to non-traditional foods [74].

After performing the evaluation of the measurement model, which only considers the remaining attributes, the confirmatory factor analysis yielded a good model fit, consistently loading on two factors. The results indicate the presence of two stable categories. Factor 1 includes eight items, representing eight attributes, related to "how the food is produced" (Cronbach's $(\alpha)=0.91)$, and Factor 2 has two items associated with "local food", representing the category "how the food is grown" $(\alpha=0.86)$. The good reliability of the scale falls in line with those previously employed for naturalness, such as the most broadly-used one developed by Steptoe et al. [11] $(\alpha=0.84)$ and the newest by Michel and Siegrist [22] ( $\alpha=0.95)$. Results suggesting both reliability and convergent validity of the construct revealed that "local" represents an important attribute of food naturalness in terms of millennial consumers. The findings support previous research that suggests millennials are more likely to support local food production [20]. In previous studies, local food production was found to preserve the natural attributes in foods [48] and had a significant impact on the intention to eat more natural [40] and authentic products [75]. This study also confirmed the positive effect of naturalness categories analyzed in the present research on millennials' trust in natural food. The findings support existing knowledge that considers authenticity as being "highly entangled in the trust-building process" ([61], 
p. 228). Thus, the market-based strategies enacted by the food business need to develop the means to build millennials' trust towards natural food.

\section{Conclusions}

Currently, natural food is one of the most increasingly demanded products and, as a result, its economic impact has aroused corporate interest [6]. What people expect from natural foods partly overlaps with their perception of organic foods [76], but while "organic" labeling for food is regulated [75], there are almost no regulations concerning the use of the word "natural" [22]. Previous attempts to comprehensively conceptualize food naturalness were limited to theoretical approaches (e.g., [9]) or did not take into account the singularities of the millennial generation (e.g., [22]).

A naturalness scale should refer not only to "how the food is produced" but also to other categories such as "how the food is grown" in order to properly capture the attributes considered by millennial consumers. The food industry must take these other attributes into account. Moreover, researchers must support industry development by providing an accurate definition of food naturalness and a measurement tool that comprises the way natural food is produced and processed, as well as its origin. In addition, these results show that millennials' characteristics provide opportunities for product marketing and consumer communication in terms of traditional food.

The current lack of empirical validation of food naturalness attributes within a millennial context makes this research especially pertinent. In other words, marketers in the natural food industry may consider these findings to establish a sharp food naturalness image in the minds of millennial consumers. The improvement of this model and subsequent discussions are highly recommended. In the same way, the formation of policies and communication strategies focused on food naturalness criteria would be noteworthy.

The present study has a few limitations, which also provide ample opportunities for future research. First, even though the extended model provided some novel insights into the importance of food naturalness attributes in the millennial context, the data are collected only from Spanish university students. Therefore, future research is recommended to verify the attributes in more diverse samples and geographical locations, which have the potential to bring much more theoretical richness to the proposed framework. Second, for the future, longitudinal research designs may be a promising approach to study the potentially reciprocal effects between consumers' perceived importance of food naturalness and their corresponding behavioral intentions. This could especially be the case for the effect on consumers' intention to consume natural products based on personal experience, will, and need. Third, a future study is recommended to investigate the relationship between food naturalness perception and existing public and private certification schemes, namely, organic, sustainable, and carbon footprint.

Author Contributions: Conceptualization, E.J. and E.L.-V.; Formal analysis, E.J. and E.L.-V.; Funding acquisition, E.L.-V. and M.B.G.-S.; Investigation, E.J.; Methodology, E.L.-V. and M.B.G.-S.; Supervision, E.L.-V. and M.B.G.-S.; Writing - original draft, E.J.; Writing - review \& editing, E.L.-V. and M.B.G.-S. All authors have read and agreed to the published version of the manuscript.

Funding: This research was funded by the Diputación de Ourense and Universidade de Vigo (INOU 17-10).

Acknowledgments: The paper is derived from data collected for the first author's thesis at University of Vigo. We thank the detailed suggestions of Raúl González-Castro and the anonymous reviewers for their careful reading and comments that helped improve previous versions of the paper.

Conflicts of Interest: The authors declare no conflicts of interest.

\section{References}

1. Bollani, L.; Bonadonna, A.; Peira, G. The millennials' concept of sustainability in the food sector. Sustainability 2019, 11, 2984. [CrossRef]

2. Licsandru, T.C.; Cui, C.C. Ethnic marketing to the global millennial consumers: Challenges and opportunities. J. Bus. Res. 2019, 103, 261-274. [CrossRef] 
3. Cavaliere, A.; Ventura, V. Mismatch between food sustainability and consumer acceptance toward innovation technologies among Millennial students: The case of shelf life extension. J. Clean. Prod. 2018, 175, 641-650. [CrossRef]

4. Fox, D.; Ioannidi, E.; Sun, Y.T.; Jape, V.W.; Bawono, W.R.; Zhang, S.; Perez-Cueto, F.J.A. Consumers with high education levels belonging to the millennial generation from Denmark, Greece, Indonesia and Taiwan differ in the level of knowledge on food waste. Int. J. Gastron. Food Sci. 2018, 11, 49-54. [CrossRef]

5. Allen, M.W.; Spialek, M.L. Young millennials, environmental orientation, food company sustainability, and green word-of-mouth recommendations. J. Food Prod. Mark. 2017, 24, 803-839. [CrossRef]

6. Chambers, E., V; Tran, T.; Chambers, E., IV. Natural: A $\$ 75$ billion word with no definition-Why not? J. Sens. Stud. 2019, 34, e12501. [CrossRef]

7. Murley, T.; Chambers, E., IV. The influence of colorants, flavorants and product identity on perceptions of naturalness. Foods 2019, 8, 317. [CrossRef]

8. Moscato, E.M.; Machin, J.E. Mother natural: Motivations and associations for consuming natural foods. Appetite 2018, 121, 18-28. [CrossRef]

9. Román, S.; Sánchez-Siles, L.M.; Siegrist, M. The importance of food naturalness for consumers: Results of a systematic review. Trends Food Sci. Technol. 2017, 67, 44-57. [CrossRef]

10. Pula, K.; Parks, C.D.; Ross, C.F. Regulatory focus and food choice motives. Prevention orientation associated with mood, convenience, and familiarity. Appetite 2014, 78, 15-22. [CrossRef]

11. Steptoe, A.; Pollard, T.M.; Wardle, J. Development of a measure of the motives underlying the selection of food: The food choice questionnaire. Appetite 1995, 25, 267-284. [CrossRef] [PubMed]

12. Roininen, K.; Lähteenmäki, L.; Tuorila, H. Quantification of consumer attitudes to health and hedonic characteristics of foods. Appetite 1999, 33, 71-78. [CrossRef] [PubMed]

13. Bäckström, A.; Pirttilä-Backman, A.; Tuorila, H. Willingness to try new foods as predicted by social representations and attitude and trait scales. Appetite 2004, 43, 75-83. [CrossRef] [PubMed]

14. Bonadonna, A.; Giachino, C.; Truant, E. Sustainability and mountain tourism: The millennial's perspective. Sustainability 2017, 9, 1219. [CrossRef]

15. Galati, A.; Schifani, G.; Crescimanno, M.; Migliore, G. "Natural wine" consumers and interest in label information: An analysis of willingness to pay in a new Italian wine market segment. J. Clean. Prod. 2019, 227, 405-413. [CrossRef]

16. Castellini, A.; Samoggia, A. Millennial consumers' wine consumption and purchasing habits and attitude towards wine innovation. Wine Econ. Policy 2018, 7, 128-139. [CrossRef]

17. Dhanapala, S.; Vashub, D.; Subramaniam, T. Perceptions on the challenges of online purchasing: A study from "baby boomers", generation " $X$ " and generation " $Y$ " point of views. Contad. Adm. 2015, 60, 107-132.

18. Pomarici, E.; Vecchio, R. Millennial generation attitudes to sustainable wine: An exploratory study on Italian consumers. J. Clean. Prod. 2014, 66, 537-545. [CrossRef]

19. Atkin, A.T.; Thach, L. Millennial wine consumers: Risk perception and information search. Wine Econ. Policy 2012, 1, 54-62. [CrossRef]

20. Yu, H.; Gibson, K.E.; Wright, K.G.; Neal, J.A.; Sirsat, S.A. Food safety and food quality perceptions of farmers' market consumers in the United States. Food Control 2017, 79, 266-271. [CrossRef]

21. Jang, Y.J.; Kim, W.G.; Bonn, M.A. Generation Y consumers' selection attributes and behavioral intentions concerning green restaurants. Int. J. Hosp. Manag. 2011, 30, 803-811. [CrossRef]

22. Michel, F.; Siegrist, M. How should importance of naturalness be measured? A comparison of different scales. Appetite 2019, 140, 298-304. [CrossRef] [PubMed]

23. Hilton, J. Chapter $1-$ Growth patterns and emerging opportunities in nutraceutical and functional food categories: Market overview. In Developing New Functional Food and Nutraceutical Products; Elsevier: Amsterdam, The Netherland, 2017; pp. 1-28.

24. Cavallo, C.; Materia, V.C. Insects or not insects? Dilemmas or attraction for young generations: A case in Italy. Int. J. Food Syst. Dyn. 2018, 9, 226-239.

25. Tascioglu, M.; Eastman, J.K.; Iyer, R. The impact of the motivation for status on consumers' perceptions of retailer sustainability: The moderating impact of collectivism and materialism. J. Consum. Mark. 2017, 34, 292-305. [CrossRef]

26. Su, J.; Watchravesringkan, K.; Zhou, J.; Gil, M. Sustainable clothing: Perspectives from US and Chinese young millennials. Int. J. Retail Distrib. Manag. 2019, 47, 1141-1162. [CrossRef] 
27. Pekkanen, T.-L.; Pätäri, S.; Albadera, L.; Jantunen, A. Who cares about product sustainability information at the moment of purchase? Consumer evidence from three countries. Sustain. Dev. 2018, 26, 229-242. [CrossRef]

28. Dabija, D.-C.; Băbut, R. Enhancing apparel store patronage through retailers' attributes and sustainability. A generational approach. Sustainability 2019, 11, 4532. [CrossRef]

29. Schoolman, E.D.; Shriberg, M.; Schwimmer, S.; Tysman, M. Green cities and ivory towers: How do higher education sustainability initiatives shape millennials' consumption practices? J. Environ. Stud. Sci. 2014, 6, 490-502. [CrossRef]

30. Sogari, G.; Bogueva, D.; Marinova, D. Australian consumers' response to insects as food. Agriculture 2019, 9, 108. [CrossRef]

31. Bedard, S.A.N.; Tolmie, C.R. Millennials' green consumption behaviour: Exploring the role of social media. Corp. Soc. Responsib. Environ. Manag. 2018, 25, 1388-1396. [CrossRef]

32. Caracciolo, F.; Vecchio, R.; Lerro, M.; Migliore, G.; Schifani, G.; Cembalo, L. Natural versus enriched food: Evidence from a laboratory experiment with chewing gum. Food Res. Int. 2019, 122, 87-95. [CrossRef] [PubMed]

33. Saba, A.; Sinesio, F.; Moneta, E.; Dinnella, C.; Laureati, M.; Torri, L.; Spinelli, S. Measuring consumers attitudes towards health and taste and their association with food-related life-styles and preferences. Food Qual. Prefer. 2019, 73, 25-37. [CrossRef]

34. Chambers, E., V; Chambers, E., IV; Castro, M. What is "Natural"? Consumer responses to selected ingredients. Foods 2018, 7, 65. [CrossRef]

35. Chekima, B.; Oswald, A.I.; Wafa, S.A.; Wafa, S.K.; Chekima, K. Narrowing the gap: Factors driving organic food consumption. J. Clean. Prod. 2017, 166, 1438-1447. [CrossRef]

36. Tobler, C.; Visschers, V.H.M.; Siegrist, M. Eating green. Consumers' willingness to adopt ecological food consumption behaviors. Appetite 2011, 57, 674-682. [CrossRef] [PubMed]

37. Brunner, T.A.; Van der Horst, K.; Siegrist, M. Convenience food products. drivers for consumption. Appetite 2010, 55, 498-506. [CrossRef]

38. Zhang, T.; Chen, J.; Hu, B. Authenticity, quality, and loyalty: Local food and sustainable tourism experience. Sustainability 2019, 11, 3437. [CrossRef]

39. Adams, D.C.; Salois, M.J. Local versus organic: A turn in consumer preferences and willingness-to-pay. Renew. Agric. Food. Syst. 2010, 25, 331-341. [CrossRef]

40. Loureiro, M.L.; Hine, S. Discovering niche markets: A comparison of consumer willingness to pay for local (Colorado grown), organic, and GMO-free products. J. Agric. Appl. Econ. 2002, 34, 477-487. [CrossRef]

41. Feldmann, C.; Hamm, U. Consumers' perceptions and preferences for local food: A review. Food Qual. Prefer. 2015, 40, 152-164. [CrossRef]

42. EC. Council Regulation (EC) No 834/2007 of 28 June 2007 on organic production, labelling of organic products, repealing. Regulation (EEC) no 2092/91. Off. J. Eur. Commun. 2007, L189/1,1-23.

43. Spence, C. On the changing colour of food \& drink. Int. J. Gastron. Food Sci. 2019, 17, 100161.

44. Shim, S.; Seo, S.H.; Lee, Y.; Moon, G.; Kim, M.; Park, J. Consumers' knowledge and safety perceptions of food additives: Evaluation on the effectiveness of transmitting information on preservatives. Food Control 2011, 22, 1054-1060. [CrossRef]

45. Pfukwa, T.; Fawole, O.; Manley, M.; Gouws, P.; Opara, U.; Mapiye, C. Food preservative capabilities of grape (vitis vinifera) and clementine mandarin (citrus reticulata) By-products Extracts in South Africa. Sustainability 2019, 11, 1746. [CrossRef]

46. Bearth, A.; Cousin, M.; Siegrist, M. The consumer's perception of artificial food additives: Influences on acceptance, risk and benefit perceptions. Food. Qual. Prefer. 2014, 38, 14-23. [CrossRef]

47. Siegrist, M.; Sütterlin, B. Importance of perceived naturalness for acceptance of food additives and cultured meat. Appetite 2017, 113, 320-326. [CrossRef]

48. Onyango, B.M.; Govindasamy, R.; Hallman, W.K.; Jang, H.; Puduri, V.S. Consumer acceptance of genetically modified foods in South Korea: Factor and cluster analysis. J. Agribus. 2006, 1, 1-18.

49. Renner, B.; Sproesser, G.; Strohbach, S.; Schupp, H.T. Why we eat what we eat. The eating motivation survey (TEMS). Appetite 2012, 59, 117-128. [CrossRef]

50. Dean, M.; Raats, M.M.; Shepherd, R. The role of self-identity, past behavior, and their interaction in predicting intention to purchase fresh and processed organic food. J. Appl. Soc. Psychol. 2012, 42, 669-688. [CrossRef] 
51. Garanti, Z.; Berberoglu, A. Cultural perspective of traditional cheese consumption practices and its sustainability among post-millennial consumers. Sustainability 2018, 10, 3183. [CrossRef]

52. Hemmerling, S.; Hamm, U.; Spiller, A. Consumption behaviour regarding organic food from a marketing perspective-A literature review. Org. Agric. 2015, 5, 277-313. [CrossRef]

53. Thøgersen, J.; de Barcellos, M.D.; Perin, M.G.; Zhou, Y. Consumer buying motives and attitudes towards organic food in two emerging markets. Int. Mark. Rev. 2015, 32, 389-413. [CrossRef]

54. Hinkin, T.R. Scale Development Principles and Practices. In Research in Organizations: Foundations and Methods of Inquiry; Berrett-Koehler: San Francisco, CA, USA, 2005; pp. 161-179.

55. Holt, D.T.; Armenakis, A.A.; Field, H.S.; Harris, S.G. Readiness for organizational change: The systematic development of a scale. J. Appl. Behav. Sci. 2007, 43, 232-255. [CrossRef]

56. Vega-Zamora, M.; Torres-Ruiz, F.J.; Parras-Rosa, M. Towards sustainable consumption: Keys to communication for improving trust in organic foods. J. Clean. Prod. 2019, 216, 511-519. [CrossRef]

57. Yamoah, F.; Acquaye, A. Unravelling the attitude-behaviour gap paradox for sustainable food consumption: Insight from the UK apple market. J. Clean. Prod. 2019, 217, 172-184. [CrossRef]

58. D'Amico, M.; Di Vita, G.; Monaco, L. Exploring environmental consciousness and consumer preferences for organic wines without sulfites. J. Clean. Prod. 2016, 120, 64-71. [CrossRef]

59. Padel, S.; Foster, C. Exploring the gap between attitudes and behaviour-Understanding why consumers buy or do not buy organic food. Br. Food J. 2005, 107, 606-625. [CrossRef]

60. Bonti-Ankomah, S.; Yiridoe, E.K. Organic and Conventional Food: A Literature Review of the Economics of Consumer Perceptions and Preferences; Final Report 2006; Organic Agriculture Centre of Canada (OACC): Truro, NS, Canada, 2006.

61. Hernandez-Fernandez, A.; Lewis, M. Brand authenticity leads to perceived value and brand trust. Eur. J. Manag. Bus. Econ. 2019, 28, 222-238. [CrossRef]

62. Nuttavuthisit, K.; Thøgersen, J. The importance of consumer trust for the emergence of a market for green products: The case of organic food. J. Bus. Ethics 2017, 140, 323-337. [CrossRef]

63. Siegrist, M.; Stampfli, N.; Kastenholz, H. Consumers' willingness to buy functional foods. The influence of carrier, benefit and trust. Appetite 2008, 51, 526-529. [CrossRef]

64. Hair, J.F.; Hult, G.T.M.; Ringle, C.M.; Sarstedt, M. A Primer on Partial Least Squares Structural Equation Modeling (PLS-SEM), 2nd ed.; Sage: Thousand Oaks, CA, USA, 2017.

65. Henseler, J.; Ringle, C.M.; Sarstedt, M. A new criterion for assessing discriminant validity in variance-based structural equation modeling. J. Acad. Mark. Sci. 2015, 43, 115-135. [CrossRef]

66. Chin, W.W. How to write up and report PLS analyses. In Handbook of Partial Least Squares; Esposito Vinzi, V., Chin, W., Henseler, J., Wang, H., Eds.; Springer: Heidelberg, Germany, 2010; pp. 655-690.

67. Fornell, C.; Larcker, D.F. Evaluating structural equation models with unobservable variables and measurement error. J. Mark. Res. 1981, 18, 39-50. [CrossRef]

68. Hair, J.; Sarstedt, M.; Ringle, C.; Mena, J. An assessment of the use of partial least squares structural equation modeling in marketing research. J. Acad. Mark. Sci. 2011, 40, 414-433. [CrossRef]

69. Akter, S.; D'Ambra, J.; Ray, P.K. An evaluation of PLS based complex models: The roles of power analysis, predictive relevance and GoF index. In Proceedings of the 17th Americas Conference on Information Systems, Detroit, MI, USA, 4-8 August 2011; Associaton for Information Systems: Detroit, MI, USA, 2011; p. 151.

70. Vinzi, V.E.; Trinchera, L.; Amato, S. PLS Path Modeling: From foundations to recent developments and open issues for model assessment and improvement. In Handbook of Partial Least Squares; Esposito Vinzi, V., Chin, W., Henseler, J., Wang, H., Eds.; Springer: Heidelberg, Germany, 2010; pp. 47-82.

71. Chin, W.W. Bootstrap cross-validation indices for PLS path model assessment. In Handbook of Partial Least Squares; Esposito Vinzi, V., Chin, W., Henseler, J., Wang, H., Eds.; Springer: Heidelberg, Germany, 2010; pp. 83-97.

72. Tenenhaus, M.; Vinzi, V.E.; Chatelin, Y.; Lauro, C. PLS path modeling. Comput. Stat. Data Anal. 2005, 48, 159-205. [CrossRef]

73. Barroso, C.; Carrión, G.C.; Roldán, J.L. Applying maximum likelihood and PLS on different sample sizes: Studies on SERVQUAL model and employee behavior model. In Handbook of Partial Least Squares; Esposito Vinzi, V., Chin, W., Henseler, J., Wang, H., Eds.; Springer: Heidelberg, Germany, 2010; pp. 427-447.

74. Vanhonacker, F.; Lengard, V.; Hersleth, M.; Verbeke, W. Profiling European traditional food consumers. Br. Food J. 2010, 112, 871-886. [CrossRef] 
75. Bollani, L.; Peira, G.; Varese, E.; Nesi, E.; Pairotti, M.B.; Bonadonna, A. Labelling and sustainability in the green food economy: Perception among millennials with a good cultural background. Riv. Studi Sulla Sostenibilita 2017, 2, 83-101. [CrossRef]

76. Dickson-Spillmann, M.; Siegrist, M.; Keller, C. Attitudes Toward Chemicals Are Associated with Preference for Natural Food. Food Qual. Prefer. 2011, 22, 149-156. [CrossRef]

(C) 2020 by the authors. Licensee MDPI, Basel, Switzerland. This article is an open access article distributed under the terms and conditions of the Creative Commons Attribution (CC BY) license (http://creativecommons.org/licenses/by/4.0/). 